\title{
Matrix Metalloproteinase-21 Is Expressed Epithelially During Development and in Cancer and Is Up-Regulated by Transforming Growth Factor- $\beta 1$ in Keratinocytes
}

\author{
Katja Ahokas, Jouko Lohi, Sara A. Illman, Elena Llano, Outi Elomaa, Ulla Impola, \\ Marja-Liisa Karjalainen-Lindsberg, and Ulpu Saarialho-Kere
}

Departments of Dermatology (KA, UI, US-K), Pathology (JL, SAI, M-LK-L), and Medical Genetics (OE), University of Helsinki, and Helsinki University Central Hospital, Helsinki, Finland; Departamento de Bioquimica y Biologia Molecular (EL), Instituto Universitario de Oncologia, Universidad de Oviedo, Oviedo, Spain; and Clinical Research Center (US-K), Karolinska Institute and Huddinge University Hospital, Huddinge, Sweden

\begin{abstract}
SUMMARY: Human matrix metalloproteinase-21 (MMP-21), the newest member of the MMP gene family, has been suggested to play an important role in embryogenesis and tumor progression and to be a target of the Wnt, Pax, and Notch signaling pathways. Here we report detection of MMP-21 by RT-PCR in mouse embryos aged 10.5, 12.5, 13.5, and 16.5 days, as well as in various adult murine organs. In both humans and mice, MMP-21 protein was detected in the epithelial cells of developing kidney, intestine, neuroectoderm, and skin but not in normal adult skin using immunohistochemistry with two unrelated antibodies. However, it was present in invasive cancer cells of aggressive subtypes of basal and squamous cell carcinomas, although it was not expressed in skin disorders characterized by mere keratinocyte hyperproliferation. Of several cytokines tested, transforming growth factor- $\beta 1$ induced MMP-21 in vitro in HaCaTs and keratinocytes as judged by real-time quantitative TaqMan PCR. Although suprabasal differentiating keratinocytes expressed MMP-21 in developing skin in vivo, MMP-21-positive keratinocytes were detected by immunohistochemistry in both low and high calcium cultures. MMP-21 expression was not up-regulated by ras transformation in HaCaT cell lines (HaCaT, A5, II-4, and RT3); in skin and colon cancers, its expression did not associate with apoptosis, $\beta$-catenin transactivation, or epithelial MMPs- 9 and -10 . However, MMP-21 protein was found in the same regions as MMP-7 but not in the same cells. Our results suggest that during development, MMP-21 expression is temporally and spatially tightly controlled. Unlike many classical MMPs, it is present in various normal adult tissues. Among epithelial MMPs, MMP-21 has a unique expression pattern in cancer. (Lab Invest 2003, 83:1887-1899).
\end{abstract}

$T$ he matrix metalloproteinase (MMP) enzyme family comprises more than 20 human members capable of degrading most, if not all, extracellular matrix and basement membrane components at least in vitro (Lohi et al, 2001; Nagase and Woessner, 1999; Uría and López-Otín, 2000). Furthermore, these human enzymes activate certain growth factors and shed several cell surface molecules (McCawley and Matrisian, 2001). MMP-21, the newest member of this family, was recently cloned from human placenta cDNA (Ahokas et al, 2002). It is a secreted 57-kDa protein that contains a signal sequence, a prodomain with a PRCGVPD motif, a zinc-binding catalytic do-

DOI: 10.1097/01.LAB.0000106721.86126.39

Received May 22, 2003.

This study was supported by grants from the Cancer Foundation of Finland, Academy of Finland, the Sigrid Juselius Foundation, Finska Läkaresällskapet, and Helsinki University Central Hospital Research Funds.

Address reprint requests to: Dr. U. Saarialho-Kere, Department of Dermatology, Helsinki University Central Hospital, Meilahdentie 2, FIN-00250 Helsinki, Finland.E-mail: ulpu.saarialho-kere@helsinki.fi main with an HEIGHVLGL sequence, and a hemopexin-like domain flanked by two cysteine residues. Furthermore, MMP-21 has a furin activation sequence but no transmembrane sequence nor a cytoplasmic domain. Based on its structure, MMP-21 can be grouped in the same subgroup of convertaseactivated MMPs as stromelysin-3 and epilysin (Overall and López-Otín, 2002). Comparison of the amino acid sequence of MMP-21 with the other MMPs indicates that it is most closely related to some other recently cloned members of the enzyme family, such as MMP$17,-23$, and -25 (Ahokas et al, 2002). No physiologic activators or substrates for MMP-21 have yet been identified. However, MMP-21 is able to degrade $\alpha 1$ antitrypsin (Marchenko et al, 2003), but because this is a general substrate for most MMPs, this capability does not give any insight on its physiologic substrates.

MMP-21 has been previously described in Xenopus laevis and in Cynops pyrrhogaster (XMMP and CyMMP, respectively) (Suzuki et al, 2001; Yang et al, 1997). Furthermore, the sequence of the murine MMP-21 gene was submitted to GenBank independently by two groups (Accession Numbers: AF507967 and AY124569). The cloning 
of the murine MMP-21 was very recently published (Marchenko et al, 2003). MMP-21 has been implicated in the development of neural tissues in both humans and mice (Ahokas et al, 2002; Marchenko et al, 2003).

The 2.5-kb human MMP-21 mRNA is detectable by standard Northern blotting analysis only in fetal liver (Ahokas et al, 2002), suggesting low expression levels in the tissues, as is typical for many of the novel MMPs (Marchenko et al, 2001, 2003; Uría and López-Otín, 2000). Using RT-PCR analysis, we detected MMP-21 in various human fetal and adult tissues and epithelial cancer cell lines. Expression of MMP-21, as assessed by immunohistochemistry, was largely restricted to the epithelium and the tumor cells themselves (Ahokas et al, 2002), a typical feature of matrilysin-1 (Fingleton et al, 2001) and stromelysin-2 (Kerkelä et al, 2001). Other MMPs, in contrast, are primarily expressed in vivo by stromal cells.

The purpose of this study was to investigate the role and cellular origin of MMP-21 during human and murine development to gain insights into its biologic functions. Furthermore, because MMP-21 has been shown to be primarily expressed by epithelium in vivo, its regulation and expression in epithelial cell lines and skin cancer were also examined.

\section{Results}

\section{MMP-21 mRNA Expression During Murine Development}

In mouse embryos, MMP-21 was detected by RT-PCR in embryos aged 10.5, 12.5, 13.5, and 16.5 days after conception, with the expression being most abundant at the age of 13.5 days (Fig. 1). No expression was detected in a 7-day embryo in agreement with previous findings (Marchenko et al, 2003). In the same experiment, expression of MMP-21 was also observed in adult murine colon, heart, brain, spleen, lung, liver, skeletal muscle, kidney, testis, and skin with varying intensities, with the highest MMP-21 expression levels in the heart, brain, lung, liver, and skeletal muscle (Fig. 1). The specificity of these transcripts was verified by sequencing. In addition, MMP-21 could be detected in adult murine ovary, pregnant uterus, and newborn animals by RT-PCR (data not shown).

\section{Localization of MMP-21 Protein in Developing Murine and Human Organs}

To define the physiologic and pathologic roles and the cellular source of MMP-21, we examined the expression patterns of this enzyme in a variety of developing murine tissues by immunohistochemical staining. Polyclonal MMP-21 antibodies were originally raised against a peptide in the hemopexin domain, which differs by only one amino acid residue between the human and the mouse MMP-21 and, thus, the same antibodies could successfully be used in murine tissue samples as well. In addition, some fetal samples were stained as previously described (Marchenko et al, 2003) using commercial RP3MMP-21 rabbit antibodies (1:300; Triple Point Biologics, Portland, Oregon) to
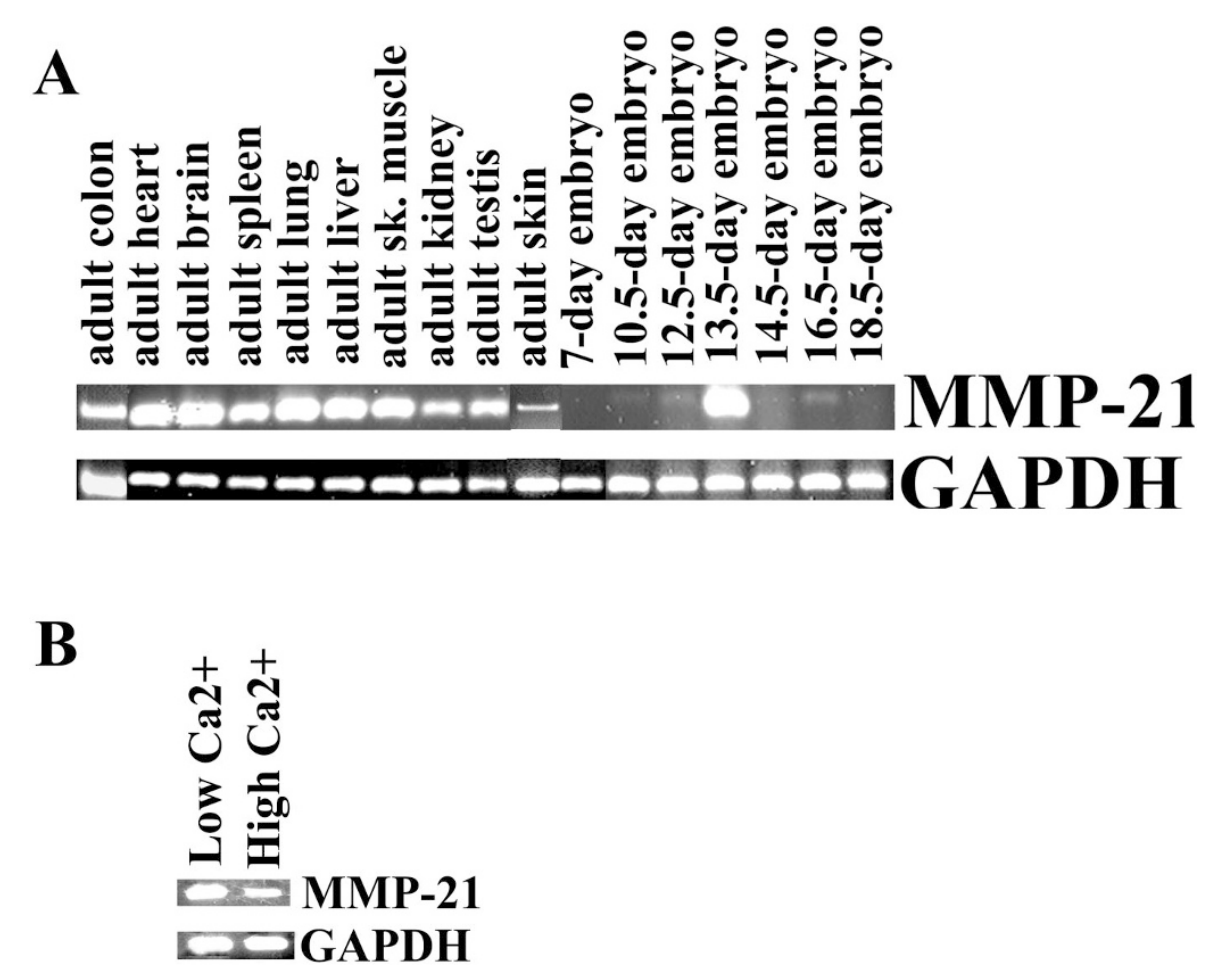

Figure 1.

Matrix metalloproteinase-21 (MMP-21) is expressed by RT-PCR in developing mouse and various adult mouse tissues and murine keratinocytes. A, Panel PCR revealed the correct 291-bp band for murine MMP-21 in the colon, heart, brain, spleen, lung, liver, skeletal muscle, kidney, testis, and skin of the adult mouse. In mouse embryos, MMP-21 expression is seen at days 10.5, 12.5, 13.5, and 16.5. Amplification of GAPDH (177-bp band) was used to ascertain equal loading and integrity of the cDNA in each reaction. B, Murine keratinocytes were cultured in low and high calcium, and RT-PCR was performed as described in "Materials and Methods." 
confirm the results. MMP-21 was detected in mouse placenta at 16 days (not shown) in agreement with our previous human data (Ahokas et al, 2002). Furthermore, it was detected in several developing murine organs of ectodermal origin such as the kidney and the skin (Fig. 2, A and C). However, expression of MMP-21 in adult murine skin was very low compared with many other organs, as assessed by RT-PCR (Fig. 1A). This was in agreement with our negative immunostaining results in adult murine skin (Fig. 2G).

We and others have previously used RT-PCR to show that MMP-21 is present in developing human brain, kidney, and liver (Ahokas et al, 2002; Marchenko et al, 2003). To study the cellular origin of MMP-21, we immunostained selected human fetal samples with polyclonal antibodies. During human development, MMP-21 was evident in developing neuroectoderm at 10 weeks of gestation (Ahokas et al, 2002), kidney tubules at 10 to 14 weeks, apically in the esophagus, colon, and ileum at 7 to 14 weeks, and in developing bronchi at 12 weeks (Fig. 3, A to E). The immunoreactivity increased clearly between 7 and 14 weeks.

\section{Expression of MMP-21 in Skin and Malignant Cutaneous Cell Lines}

We have previously shown that MMP-21 can be detected by RT-PCR in the malignant A-431 squa- mous cell cancer (SCC) cell line (Ahokas et al, 2002) in addition to its predominantly epithelial character in developing tissues and cancers. Thus we were interested to examine whether MMP-21 expression is also associated with cutaneous SCCs in vivo. Using immunohistochemistry, MMP-21 was absent from normal skin (Fig. 4G) and specimens of three skin diseases characterized by epidermal hyperproliferation, namely Bowen's disease, psoriasis, and chronic wounds (Fig. $4, E$ and F). In normally healing wounds, MMP-21 protein was not detected in migrating keratinocytes (not shown). MMP-21 protein was detected in two of eight basal cell cancers: only tumors representing the aggressive sclerosing subtype were positive (Fig. 4D). Eleven of 21 SCCs demonstrated cytoplasmic staining for MMP-21 in occasional tumor cells at the invasive front, particularly in dedifferentiated and aggressive grade III tumors (Fig. 4, A and C).

Because it has been suggested that MMP-21 is a direct target of $\beta$-catenin transactivation, like matrilysin-1 in certain tumors (Crawford et al, 1999), or related to apoptosis (Marchenko et al, 2003), adjacent sections from SCCs and colon cancers were immunostained for MMP-21 and $\beta$-catenin/apoptosis $(n=$ 8). In skin cancer, MMP-21-positive cells were devoid of normal membranous $\beta$-catenin, which suggests abnormal adhesion, but the cells did not demonstrate
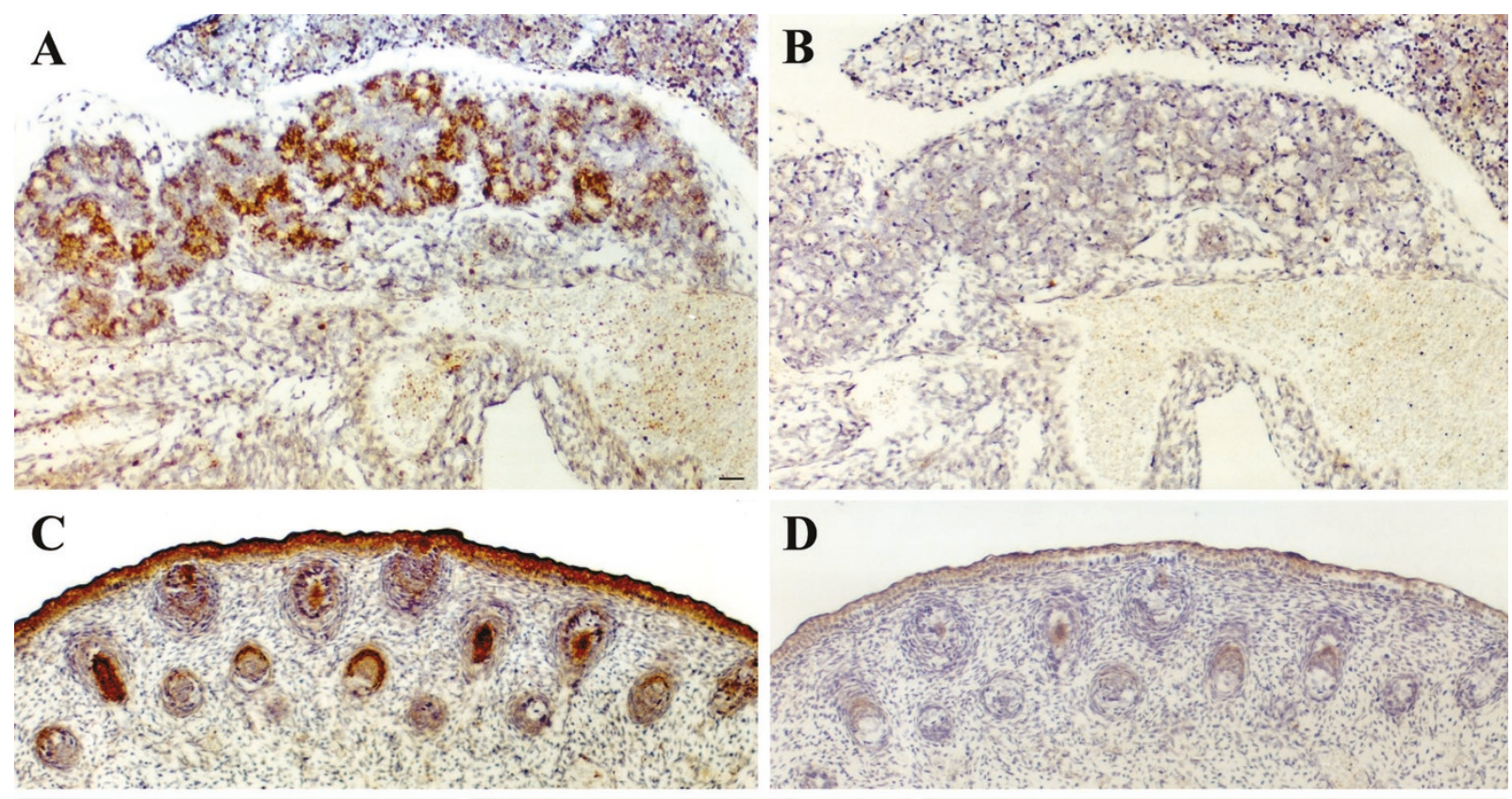

D
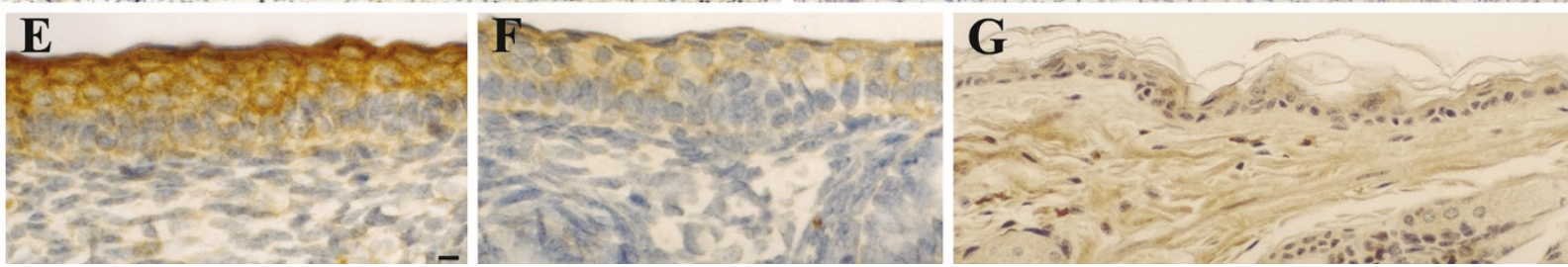

Figure 2.

MMP-21 is expressed in the epithelium during murine development. MMP-21 protein is detected in developing kidney (A) and skin (C). B and D, Corresponding negative controls done with peptide blocking. E, Higher magnification of developing skin from E16 in C. F, Higher magnification of D. G, Immunostaining for MMP-21 in adult murine skin. Scale bars: $25 \mu \mathrm{m}(\mathrm{A}, \mathrm{B}, \mathrm{G}) ; 50 \mu \mathrm{m}$ (C and D), $12.5 \mu \mathrm{m}$ ( $E$ and $\mathrm{F})$. 


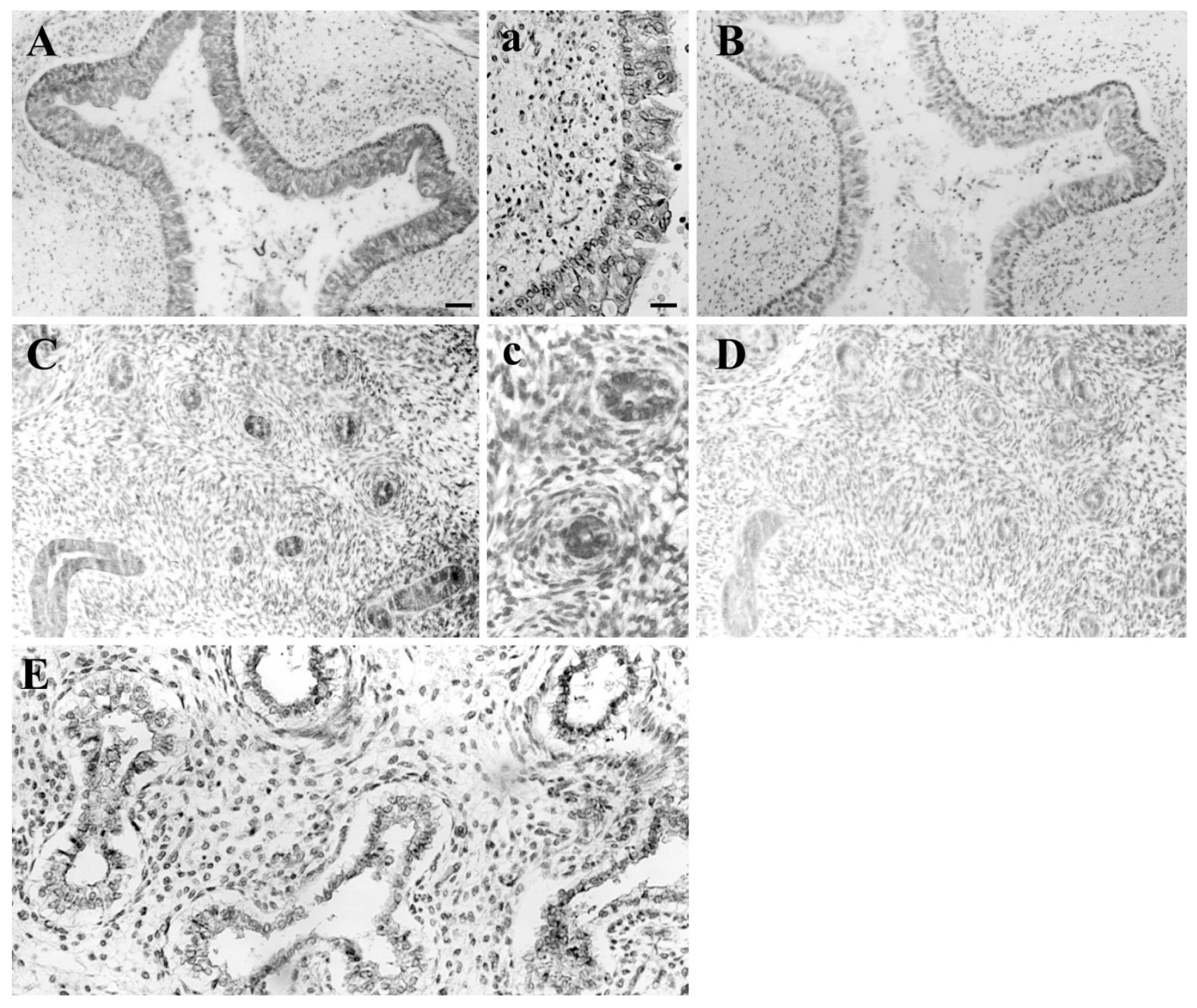

Figure 3.

MMP-21 protein is detected in several ectodermal organs during human fetal development. A, C, and E, Immunostaining for MMP-21 in developing intestine, kidney, and bronchi. a and C, Higher magnification of positive areas in A and C. B and D, Corresponding negative controls done with preimmune serum. Scale bars: $50 \mu \mathrm{m}$ (A to D); $25 \mu \mathrm{m}$ (a, C, and $\mathrm{E}$ ).

cytoplasmic or nuclear accumulation of this protein either (not shown). In colon cancer, MMP-21-positive cells did not colocalize with cells demonstrating nuclear or cytoplasmic $\beta$-catenin (Fig. 5, A and B). No association of apoptosis with MMP-21-positive cells was detected in SCCs or colon cancer (not shown). Because the putative promoter regions of MMP-21 and another epithelial MMP, stromelysin-2, are very similar, MMP-10 mRNA was studied on serial sections of 10 SCCs with MMP-21, but they did not colocalize (not shown). However, matrilysin-1 expression was often detected in the same regions as MMP-21 in both skin and colon cancers (Fig. 5, C and D), although they did not colocalize in the same cells (Fig. 5, E and F).

\section{Expression of MMP-21 in Transfected Cells}

The full-length human MMP-21 coding sequence was cloned into the pEFIRES-P expression vector under the control of the EF- $1 \alpha$ promoter. This vector was transfected into human embryonal kidney epithelial cells $293 \mathrm{~A}$, primarily to study the localization of this protein and secondarily to further confirm the specificity of our peptide antibodies. Transfection experiments using empty pEFIRES-P vector without the MMP-21 insert were performed in parallel. In agreement with Figure 7A, cytoplasmic staining for MMP-21 was detected in transfected cells, whereas the empty vector controls were negative (not shown).

\section{Production of MMP-21 mRNA Is Induced by Transforming

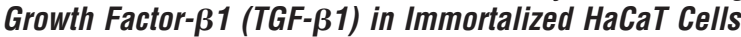

We cultured HaCaT cells on plastic in the presence of various cancer-related cytokines and growth factors. Total RNA from these cells was analyzed using the TaqMan quantitative real-time PCR (Kerkelä et al, 2002; Rechardt et al, 2000). The basal level for MMP-21 expression was low in HaCaTs. After 18, 24, or 48 hours of treatment with PMA, epidermal growth factor (EGF), IGF, basic fibroblast growth factor (bFGF), TNF- $\alpha$, or vascular endothelial growth factor 


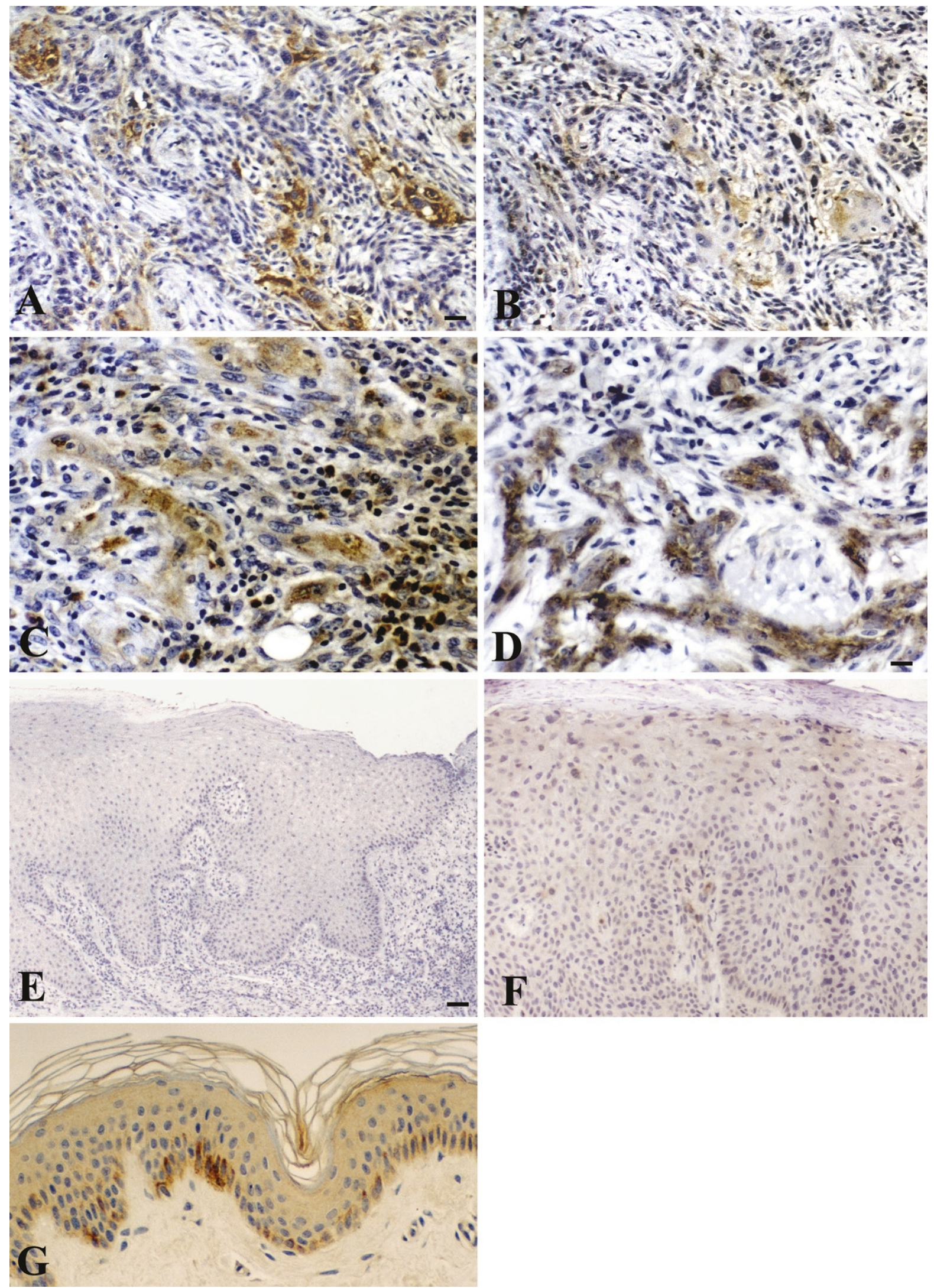

Figure 4.

MMP-21 protein is up-regulated in skin cancer but not associated with benign keratinocyte hyperproliferation. A, MMP-21 protein detected by immunohistochemistry in a grade III squamous cell cancer (SCC). B, Corresponding control done with peptide blocking. C, Higher magnification of MMP-21-positive cancer cells in another SCC. D, Positive cancer cells in a sclerosing basal cell cancer. No MMP-21 protein is detected in chronic wounds (E), in Bowen's disease (F), or in normal adult skin (G). Brown staining seen in occasional basal cells is caused by melanin. Scale bars: $50 \mu \mathrm{m}(\mathrm{A}$, B, and F); $25 \mu \mathrm{m}(\mathrm{C}, \mathrm{D}$, and G); $125 \mu \mathrm{m}(\mathrm{E})$. 

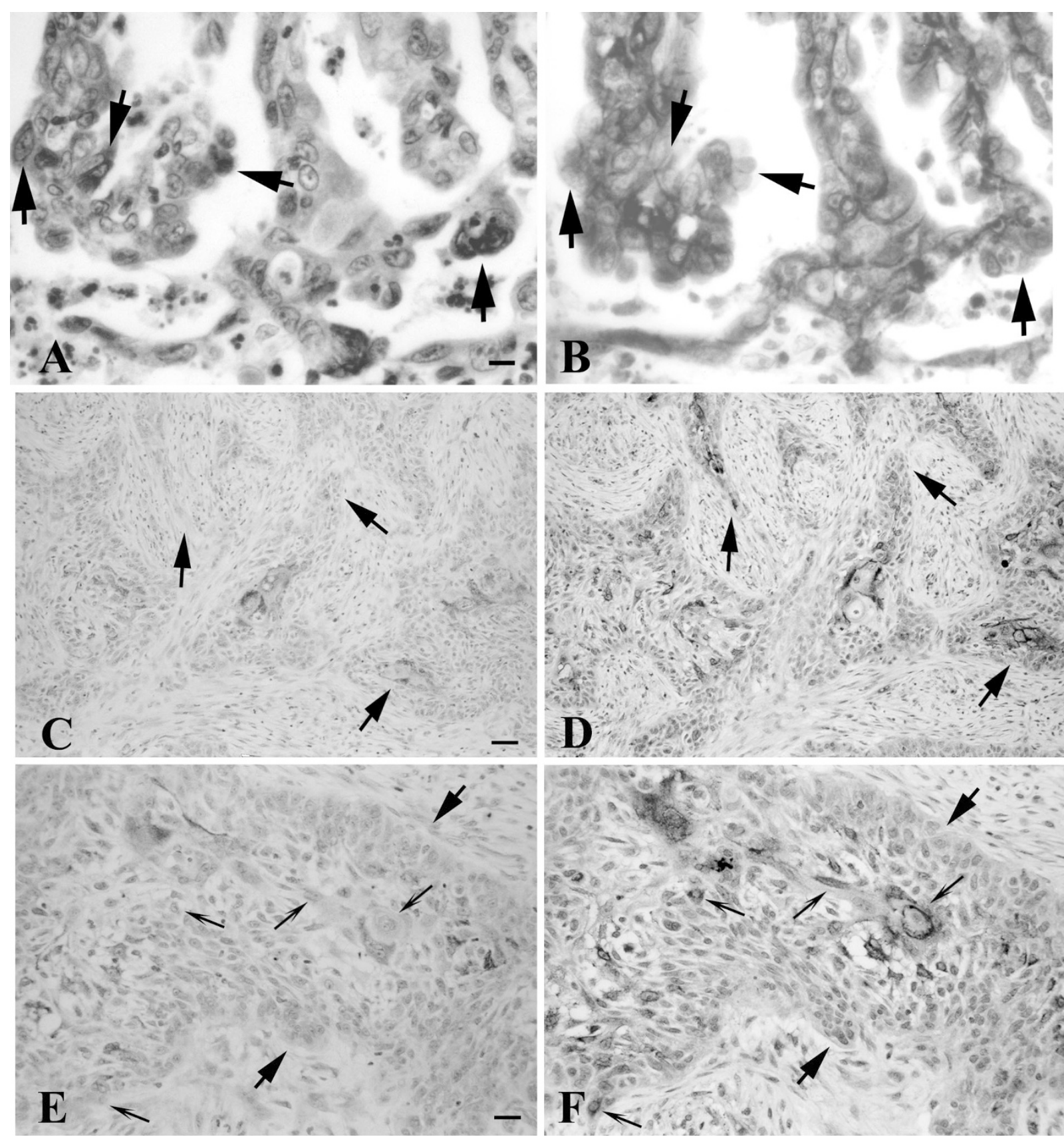

\section{Figure 5.}

Immunohistochemical analysis of MMP-21 and $\beta$-catenin or matrilysin-1 in consecutive sections. A, Cells expressing MMP-21 protein in colon cancer are devoid of nuclear or cytoplasmic staining for $\beta$-catenin (B). Arrows depict corresponding cells. MMP-21 (C) and MMP-7 (D) proteins are detected in the same regions in an SCC. E and F, Corresponding higher magnifications reveal that MMP-21 and -7 do not colocalize in the same cells. Large arrows depict corresponding areas; small arrows show MMP-7-positive but MMP-21-negative cells. Scale bars: $12.5 \mu \mathrm{m}$ (A and B); $50 \mu \mathrm{m}$ (C and D); $25 \mu \mathrm{m}$ (E and F).

(VEGF), there was no significant up-regulation of MMP-21 in these cells (Fig. 7A). Conversely, in HaCaTs, TGF- $\beta 1(10 \mathrm{ng} / \mathrm{ml})$ induced the production of MMP-21 approximately 3-fold (Fig. 6A). Up-regulation of MMP-10 in HaCaTs by TGF- $\beta 1$ was monitored as a control (Rechardt et al, 2000).

As evidenced by TaqMan analysis and conventional RT-PCR, primary keratinocytes expressed basally low levels of MMP-21 mRNA that was not essentially different from that of HaCaTs (Fig. 6C). TGF- $\beta 1$ upregulated MMP-21 mRNA also in these cells (Fig. 6, B and C), whereas EGF and bFGF showed no stimulation. Treatment of primary keratinocytes with high calcium (one patient), VEGF, PMA, or IGF did not up-regulate MMP-21 mRNA expression (not shown). Also, MMP-21 protein was detected by immunostaining in human keratinocytes cultured in low and high calcium (Fig. 7, A and B). Adult murine keratinocytes were also cultured in high and low calcium. Analogously to the human cells, differentiation induced by high calcium concentration did not up-regulate MMP-21 as assessed by RT-PCR (Fig. 1B). 

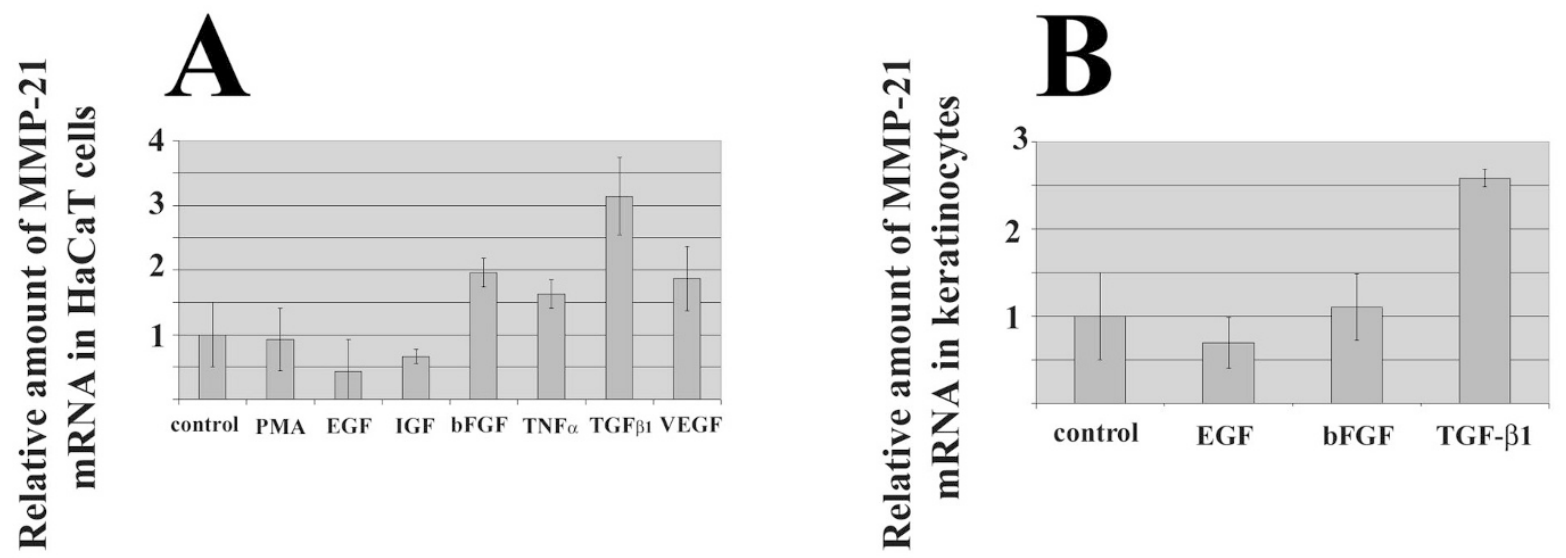

\section{C}

\section{D}
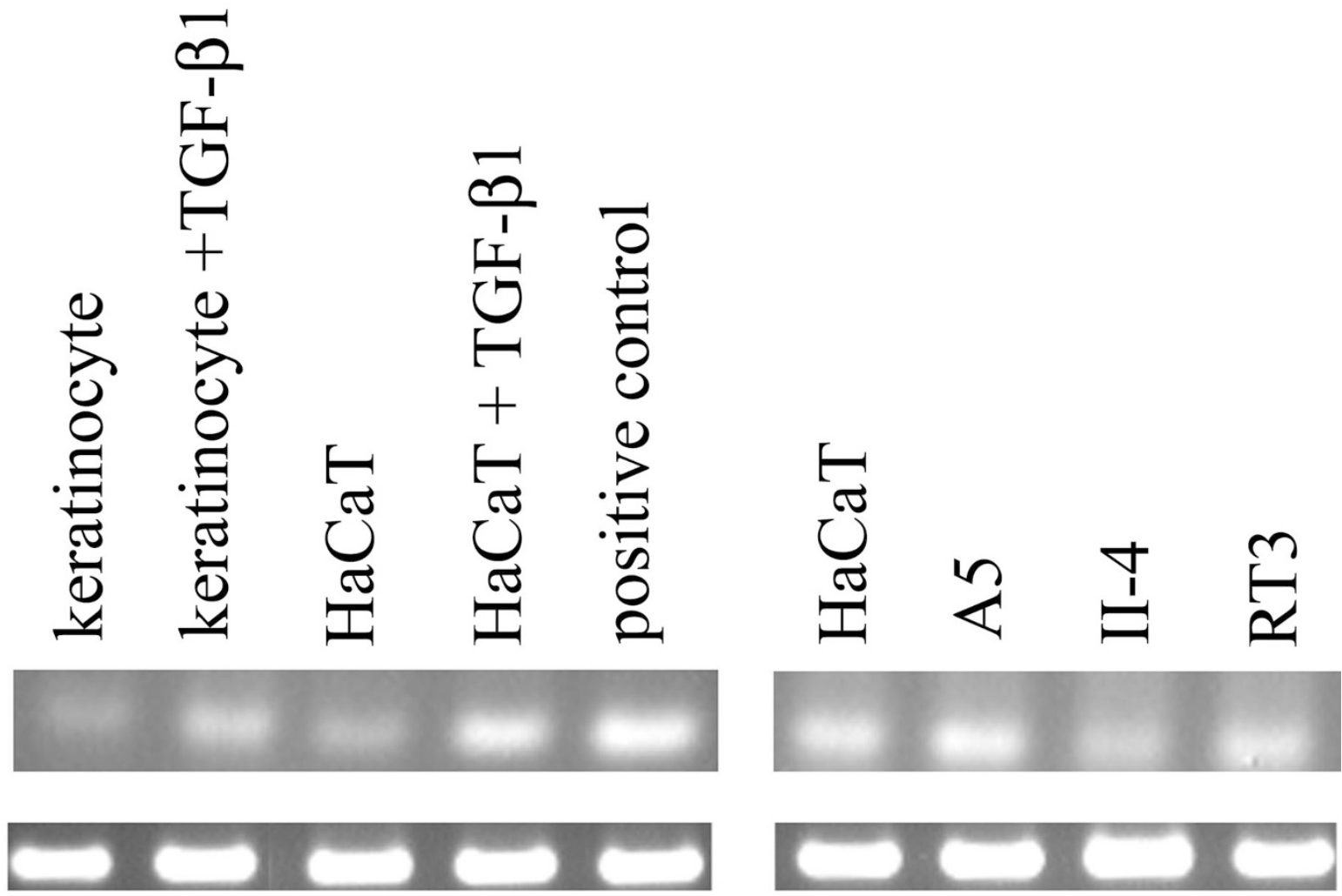

Figure 6.

MMP-21 is up-regulated in keratinocytes and HaCaT cells by transforming growth factor- $\beta 1$ (TGF- $\beta 1$ ). HaCaT cells were cultured in DMEM with $10 \%$ FCS (A) and primary keratinocytes in KBM (B) and supplemented as described in "Materials and Methods." Cells without treatment were used as controls. Total RNA was extracted, reverse transcribed, and analyzed by real-time quantitative RT-PCR (Taqman, Applied Biosystems) using GAPDH as an endogenous control. Results are shown relative to mRNA levels from control cells, assigned the value 1. C, Expression of MMP-21 (upper lane) and GAPDH (lower lane) in transformed (HaCaT) and normal keratinocytes by RT-PCR. HaCaT cells and normal keratinocytes were cultured as described above. Both cultures were treated with $10 \mathrm{ng} / \mathrm{ml}$ of TGF- $\beta 1$ for 24 hours Total RNA was reverse transcribed to CDNA, and RT-PCR was performed as described in "Materials and Methods." A total of 293 cells transfected with MMP-21 (lane 5) were used as a positive control for MMP-21 expression. D, Expression of MMP-21 mRNA in HaCaT-ras clones by RT-PCR from another experiment. The cells were cultured in DMEM as described in "Materials and Methods." Total RNA was reverse transcribed to CDNA, and reverse transcriptase PCR was performed

Although HaCaT cells were positive, MMP-21 was not up-regulated in either subconfluent or confluent cultures of cell lines with ascending tumorigenicity (HaCaT, A5, II-4, and RT3) as judged by Taqman analysis (not shown), conventional RT-PCR (Fig. 6), and immunohistochemical staining of cultured cells (not shown).

Because we have previously shown that MMP-21 is expressed by MCF7 breast cancer cells (Ahokas et al, 2002) and also in breast cancer in vivo (not shown), we 


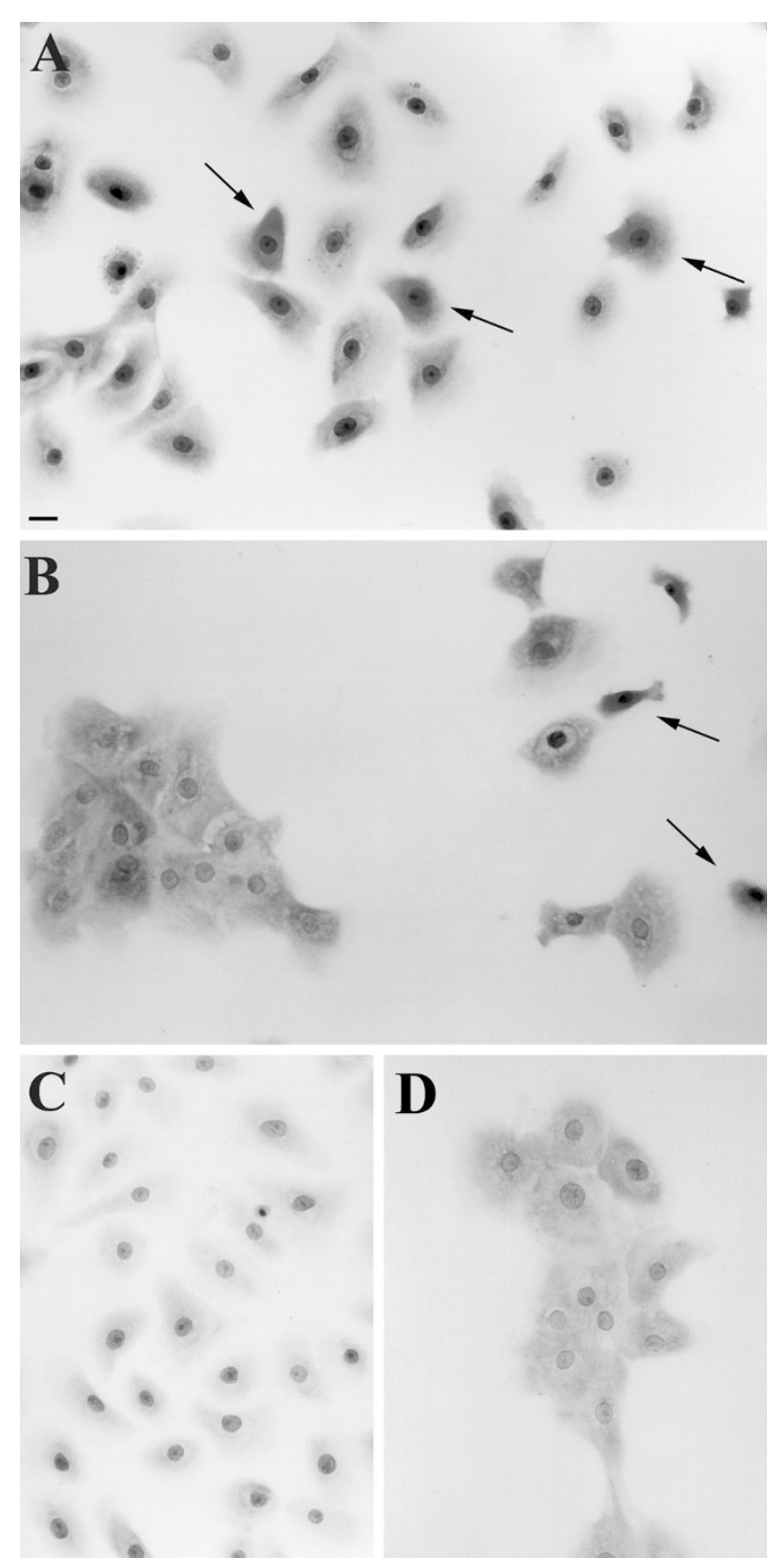

Figure 7.

Primary human keratinocytes in culture express MMP-21 protein. A, Intracytoplasmic staining for MMP-21 (arrows) in individual keratinocytes cultured in low calcium. B, Differentiating keratinocytes cultured in high calcium. Negative control (preimmune serum) for cells cultured in low calcium (C) and high calcium (D). Cells were cultured on plastic LabTek chamber slides, aminoethylcarbazole was used as chromogenic substrate, and counterstaining was performed with hematoxylin. Scale bar: $12.5 \mu \mathrm{m}$ (A to D).

treated MCF7 cells with the same cancer-related cytokines as the HaCaT cells. However, none of the following agents, PMA, EGF, IGF, bFGF, TNF- $\alpha$, TGF$\beta 1$, and VEGF, up-regulated MMP-21 expression.

\section{Discussion}

In this work we demonstrate that MMP-21 is produced in vivo in a spatially and temporally regulated manner during the development of various ectodermal structures both in mice and humans. In developing mice, MMP-21 expression can be detected by RT-PCR with varying intensity in embryos aged $10.5,12.5,13.5$, and 16.5 days. In addition to previously reported expression in mouse brain and liver (Marchenko et al, 2003), MMP-21 expression was also detected in colon, heart, spleen, lung, skeletal muscle, kidney, and testis of the adult mouse. Whether MMP-21 activity is needed for degradation of some matrix component, for invasion of certain cells, or for branching morphogenesis is currently not known (Vu and Werb, 2000). MMP-21 expression is mostly epithelial, thus it may not be essential for angiogenesis but may be required for development of skin or of ductal structures characteristic for the intestine and kidney. The promoter of MMP-21 has been suggested to possess several regulatory motifs that have been implicated to function in development (Marchenko et al, 2003). The presence of the Tcf-4 element suggests that the MMP-21 promoter is a likely target of the Wnt pathway, which has been implicated in hair follicle formation and is known to interact with TGF- $\beta 1$ pathways (Li et al, 2003). The presence of Pax-2, -5 , and -8 elements in the promoter suggests that MMP-21 may be important in the development of the kidneys, leukocytes, and thyroid, because Pax-2, -8, and -5 participate in the morphogenesis of the kidney and thyroid, and in hematopoiesis, respectively (Chi and Epstein, 2002) This agrees with our current and previous (Ahokas et al, 2002) immunohistochemical data. A third important element of the MMP-21 promoter, the Notch motif, has been linked to central nervous system development (del Barco Barrantes et al, 1999).

The Xenopus laevis ortholog for MMP-21 (XMMP) is undetectable in the blastula stage, induced in gastrula state embryo, expressed in neurula, and then downregulated in the pretailbud embryo (Yang et al, 1997). In early vertebrate development, the expression of the MMP-21 counterpart has been shown to be tightly regulated both time wise and spatially (Suzuki et al, 2001). However, MMP-21 seems to be expressed also in various adult mouse tissues (this study) as well as in human adult brain, lung, testis, ovaries, colon, and leukocytes (Ahokas et al, 2002). Thus, MMP-21 behaves unlike many of the classic MMPs that are rarely produced in normal tissues without inflammatory or oncogenic stimuli; this may implicate a role for MMP-21 in normal tissue homeostasis or turnover. Matrilysin-1, however, provides one exception, because it is present in epithelial ductal structures of various adult human organs (Saarialho-Kere et al, 1995).

Unlike many other MMPs, MMP-21 does not seem to play a role in epithelial repair (Saarialho-Kere et al, 2002). Furthermore, our in vivo data suggest that it is not up-regulated by mere keratinocyte hyperproliferation, in contrast to MMPs-19 and -28 (Impola et al, 2003; Saarialho-Kere et al, 2002). MMP-21 was present in vivo in both developing murine and human skin, whereas it could no longer be detected in fully developed skin. A low level of MMP-21 was detected, however, in unstimulated adult keratinocyte cultures by RT-PCR. This may be explained by the common feature of many MMPs: they are made by cultured 
cells in vitro but only rarely seen in normal intact tissues in vivo. For example, MMP-9 protein is produced by keratinocytes in culture but seen in the epidermis in vivo only in association with migrating keratinocytes during wound repair or in some skin cancers (Kerkelä and Saarialho-Kere, 2003). The location of MMP-21 in suprabasal keratinocytes of embryonic skin (murine 16 days, human 19 weeks) suggests that it may be linked to epidermal differentiation and disappearance of the periderm.

Of several cancer-related cytokines tested, MMP-21 was up-regulated in primary keratinocytes and $\mathrm{HaCaT}$ cells by TGF- $\beta 1$, which either up- or down-regulates several other MMPs, depending on the cell type (Gold et al, 2000). TGF- $\beta 1$ has been shown to induce MMP-1, MMP-10, and MMP-9 in primary keratinocytes (Han et al, 2001; Rechardt et al, 2000). Thus adjacent sections of six SCCs were immunostained for MMP-9, but no colocalization was detected (not shown). TGF- $\beta 1$ has been implicated in the formation of mesenchymal condensates and in epithelial morphogenesis of many organs ( $\mathrm{Li}$ et al, 2003). During wound healing TGF- $\beta 1$ increases migration (Zambruno et al, 1995). In normal keratinocytes, TGF- $\beta 1$ inhibits growth and proliferation (Gold et al, 2000); this also applies to HaCaT cells but not to the more malignant A-431 cells (Lange et al, 1999).

In tumorigenesis TGF- $\beta 1$ has a multifactorial role: at early stages it may act as a tumor suppressor and during malignant progression as a tumor promoter (Lange et al, 1999). Macrophages can produce TGF$\beta 1$, which in turn can stimulate production of invasion associated proteinases by tumor and stromal cells. Interestingly, increased expression of TGF- $\beta$ isoforms has been observed in a variety of human carcinomas, including colon, breast, prostate, and bone (Gorsch et al, 1992; Kloen et al, 1997; Truong et al, 1993)—all tumors that also express MMP-21 (Ahokas et al, 2002; and unpublished data). Based on the structure of MMP-21, synthetic furin inhibitors might offer another way of counteracting it (Bassi et al, 2003).

$\mathrm{HaCaT}$ cells together with A5 (benign), II-4 (invasive, malignant), and RT3 (invasive, metastasizing, and malignant) cells provide a unique model for human skin carcinogenesis, because these cell lines represent different grades of tumorigenic development (Boukamp et al, 1988; Fusenig and Boukamp, 1998). Surprisingly, these ras-transformed counterparts of the spontaneously immortalized keratinocyte cell line HaCaT did not express MMP-21 more abundantly than basal HaCaTs. It is known that the growth inhibitory response to TGF- $\beta$ progressively decreases with increasing malignant potential in these cell lines (Game et al, 1992). Basal HaCaTs are known to be more immunoreactive for TGF- $\beta 1$ than the other cell lines (Bachmeier and Nerlich, 2002), and this may partly explain the fact that no up-regulation of MMP-21 mRNA production was detected even in the invasive malignant cell line RT3 compared with the more benign $\mathrm{HaCaT}$ ras clones. Another explanation may be that some other oncogene than ras is responsible for up-regulation of MMP-21 in malignant cells.
The promoter region of MMP-21 is likely to contain putative binding sites for T-cell factor-4, Pax, and Notch motifs (Marchenko et al, 2003), suggesting unconventional regulation among MMPs. By comparing human and mouse genomic sequences preceding MMP-21, we found a 100-bp putative promoter region showing $80 \%$ homology between mice and humans. In this area, 350-bp upstream of the TATA-box, a putative $\mathrm{Sp}-1$ site could be detected. $\mathrm{Sp}-1$ is required for early embryogenesis and regulates terminal differentiation state of cells by affecting the methylation of DNA CpG islands (Marin et al, 1997). This transcription factor participates in the regulation of the p21 gene by TGF- $\beta$, and HaCaT cells are known to exhibit a dramatic induction of p21 gene in response to TGF- $\beta$ (Pardali et al, 2000). Sp-1 element is also found in the promoters of several other MMPs, such as MMP-2, MMP-11, MMP-14, and MMP-28 (IIIman et al, 2001; Overall and López-Otín, 2002). TNF- $\alpha$ did not upregulate MMP-21 in epithelial cells, suggesting that the NF- $\kappa$ B pathway is not relevant in its up-regulation in keratinocytes (Han et al, 2001).

Based on recent promoter studies (Marchenko et al, 2003), we also examined the relation of MMP-21 to the presence of apoptosis, accumulation of $\beta$-catenin, and expression of MMP-10. No association with these was detected in vivo in skin or in colon cancers. Because MMP expression is clearly dependent on cell and cancer type, we cannot exclude opposite findings in other tumors. However, the expression of matrilysin-1 and the expression of MMP-21 resemble each other judged by regions of expression in cancer and the presence of the corresponding proteins in normal adult tissues.

Additional studies using knock-out mice will be required to elucidate the precise role of MMP-21 in remodeling processes occurring during development. Production of recombinant MMP-21 in bacterial cells will facilitate studies on putative substrates. Studies on larger well-characterized epithelial cancer materials are underway to determine the clinical and prognostic significance of MMP-21 during tumor initiation, growth, and metastasis.

\section{Materials and Methods}

\section{Reagents}

Cell culture media, cytokines, and chemicals were obtained from Sigma (St. Louis, Missouri), FCS from BioWhittaker (Berkshire, United Kingdom), cell culture plastic ware and Lab-Tek chamber slides from Nunc (Naperville, Illinois), and thermostable polymerases from Applied Biosystems (Warrington, United Kingdom).

\section{Cell Cultures}

The immortalized keratinocyte cell lines HaCaT, A5, II-4, and RT3 (Boukamp et al, 1990) were a gift from Prof. Norbert E. Fusenig. They were cultured at $37^{\circ} \mathrm{C}$ in a humidified atmosphere of $5 \% \mathrm{CO}_{2}$ and $95 \%$ air. The cells were grown in DMEM of low glucose $(1 \mathrm{~g} / \mathrm{L})$ 
supplemented with $5 \%$ heat inactivated FCS, $2 \mathrm{~mm}$ L-glutamine, $1 \mathrm{~mm}$ sodium pyruvate, $100 \mathrm{U}$ of penicillin, and $100 \mu \mathrm{g} / \mathrm{ml}$ streptomycin. The ras-transfected clones of A5, II-4, and RT3 were further given 200 $\mu \mathrm{g} / \mathrm{ml}$ geneticin to maintain their selective pressure. The medium was changed every 3 days. Cells were seeded as they reached post-confluence (2-3 days after confluence). Before trypsinization the cells were briefly treated with $0.05 \%$ EDTA in PBS. After trypsinization the cells were seeded at a dilution of $1: 10$.

Human primary keratinocytes were isolated from adult skin obtained by reductive mammoplasties, cultured, and stimulated as described previously (Impola et al, 2003). Normal keratinocytes were grown in both low $\mathrm{Ca}^{2+}$ keratinocyte growth medium (KGM; Gibco BRL-Life Technologies, Paisley, United Kingdom) (0.09 mM) and in KGM with added $\mathrm{Ca}^{2+}(1.8 \mathrm{~mm})$ to study the effect of keratinocyte differentiation on MMP-21 expression.

Murine BALB/MK-2 keratinocytes were a gift from Dr. Stuart Aaronson (National Cancer Institute, Bethesda, Maryland). They were cultured in MEM containing $0.05 \mathrm{~mm}$ (or alternatively $1.5 \mathrm{~mm}$ ) $\mathrm{Ca}^{2+}, 4 \mathrm{ng} / \mathrm{ml}$ EGF, $100 \mathrm{lU} / \mathrm{ml}$ penicillin, and $50 \mu \mathrm{g} / \mathrm{ml}$ streptomycin. When the cultures reached confluency, they were washed with and incubated further for 18 to 24 hours in EGF-free medium before preparation for RNA extraction.

MCF-7 and transfected 293A cells were grown in Eagle's modified MEM from Sigma, supplemented with 10\% FCS, $2 \mathrm{~mm}$ L-glutamine, $1 \mathrm{~mm}$ sodium pyruvate, $0.1 \mathrm{~mm}$ of nonessential amino acids, $100 \mathrm{U}$ of penicillin, and $100 \mu \mathrm{g} / \mathrm{ml}$ streptomycin. The medium was changed every 3 days, and cells were trypsinized and seeded $1: 3$ to $1: 5$ as they reached confluence.

Cells (primary human keratinocytes in high and low calcium, HaCaT, A5, II-4, RT3, transfected 293A cells, and MK-2 cells) were also cultured in Lab-Tek chamber slides for 24 to 48 hours, deprived of serum overnight, fixed in $10 \%$ formalin for 7 minutes, and immunostained as described later except that aminoethylcarbazole was used as chromogenic substrate (Saarialho-Kere et al, 2002).

\section{Cytokines and Growth Factors}

To study the regulation of MMP-21 expression, equal amounts of cells were plated on 24-well tissue culture plates. On the next day, the cells were repeatedly washed with PBS and incubated in serum-free medium for 18 to 24 hours. The cells were subsequently treated with $10 \mathrm{ng} / \mathrm{ml}$ each of PMA, EGF, IGF, bFGF, TNF- $\alpha$, TGF- $\beta 1$, or VEGF (all from Sigma) in the volumes of $500 \mu \mathrm{l}$ per well. Cells given fresh serumfree medium were used as controls. After 24 and 48 hours, total RNA was extracted from the cells.

\section{PCR Primers and Probes}

PCR primers (Sigma Genosys, Cambridge, United Kingdom) and probes (Applied Biosystems) for human
MMP-21 were designed with the computer program Primer Express 1.5 (Applied Biosystems). Primers used for the amplification were T21F 5'- GGGATCCATAATGCAACCAAA-3' (forward nucleotides) and T21R 5'- ATCCCTCACAGGAGCCATACA-3' (reverse nucleotides). The fluorogenic probe contained a reporter dye (FAM) covalently attached at the $5^{\prime}$ end and a quencher dye (TAMRA) covalently attached at the $3^{\prime}$ end. Human glyceraldehyde-3-phosphate dehydrogenase (GAPDH) labeled with VIC reporter dye (predeveloped TaqMan assay reagents for endogenous control human GAPDH; Applied Biosystems) was used as an endogenous control in quantitative real-time PCR (TaqMan).

\section{Quantitative Real-Time PCR (TaqMan RT-PCR)}

Total cellular RNA from cultured cells was extracted using the RNeasy Miniprep kit (Qiagen, Chatsworth, California) according to manufacturer's instructions. RNA was then reverse transcribed to cDNA with Taqman Reverse Transcription reagents (Applied Biosystems) with random hexamers and used as a template for Taqman real-time quantitative PCR. Reactions were performed with the ABI PRISM 7700 Sequence Detection System (Applied Biosystems) as described previously (Rechardt et al, 2000; Kerkelä et al, 2002). PCR amplifications were performed in 20- $\mu$ l volumes, MMP-21 and GADPH in separate reactions. For MMP-21 the mixture contained $5 \mu \mathrm{l}$ of 1:5 diluted cDNA, 500 nм T21F and T21R, 200 nм FAM-labeled probe, and $1 \times$ Taqman Universal Master Mix. For GADPH the mix contained $1 \mu \mathrm{l}$ of GAPDH control reagents, $5 \mu$ l of the diluted $c D N A$, and $1 \times$ Taqman Universal Master Mix. The PCR was started with 2 minutes at $50^{\circ} \mathrm{C}$ and an initial 10-minute denaturation at $94^{\circ} \mathrm{C}$, followed by a total of 40 cycles of 15 -second denaturation at $94^{\circ} \mathrm{C}$ and 1 minute of annealing and elongation at $60^{\circ} \mathrm{C}$. Stromelysin-2 (MMP-10), which is up-regulated in HaCaTs by TGF- $\beta 1$, was used as a positive control for cell treatments as described previously (Rechardt et al, 2000).

The same reactions were also performed by conventional PCR with the same primers, in separate reactions, but without fluorogenic probes. The primers were used in a final concentration of $100 \mathrm{~nm}$ each (T21F, T21R, GAPDH forward, and GAPDH reverse), $330 \mu \mathrm{M}$ of each nucleotide, $5 \mathrm{U}$ of AmpliTaq Gold Polymerase, $5.5 \mathrm{~mm} \mathrm{MgCl}_{2}$, and $5 \mu$ l of cDNA template in a $50-\mu l$ reaction. The PCR was started with 2 minutes at $50^{\circ} \mathrm{C}$ and an initial 10-minute denaturation at $94^{\circ} \mathrm{C}$, followed by a total of 40 cycles of 15 -second denaturation at $94^{\circ} \mathrm{C}$ and 1 minute of annealing and elongation at $60^{\circ} \mathrm{C}$. Finally, PCR products were analyzed in $3 \%$ agarose gel and stained with $5 \mathrm{ng} / \mathrm{ml}$ of ethidium bromide and visualized under UV light.

To assess MMP-21 expression in mice, primers were designed to exons 3 and 5 in the murine MMP-21 gene (GenBank Accession Number: AF507967). Primers used for the amplification were as follows: mMMP109, 5'GATCCACTITGATGACGACGAGCAC-3' (forward nucleotides); and mMMP108, 5'-CTCACCCTCACCTC- 
ACCATATTG-3' (reverse nucleotides). The following samples were used as templates: Mouse MTC Panel (Clontech), containing cDNA from adult mouse heart, brain, spleen, lung, liver, skeletal muscle, kidney, testis, and 7-day embryo as well as murine cDNA from embryos at the ages of 10.5, 12.5, 13.5, 14.5, 16.5, and 18.5 days after conception, uterus (nonpregnant), placenta at the ages of 13 and 16 days, and adult colon and intestine. The conditions for the PCR were as follows: primers used in a final concentration of $200 \mathrm{~nm}$ each (mMMP108, mMMP109), $200 \mu \mathrm{M}$ of each nucleotide, 2.5 $\mathrm{U}$ of AmpliTaq Gold Polymerase, $1.5 \mathrm{~mm} \mathrm{MgCl}_{2}$, and $5 \mu \mathrm{l}$ of cDNA template in a $25-\mu$ l reaction. The PCR was started with an initial 3-minute denaturation at $94^{\circ} \mathrm{C}$, followed by a total of 35 cycles of 30 -second denaturation at $94^{\circ} \mathrm{C}, 30$ seconds of annealing at $62^{\circ} \mathrm{C}$, and 30 seconds of elongation at $72^{\circ} \mathrm{C}$, followed by terminal elongation for 10 minutes at $72^{\circ} \mathrm{C}$. Finally, PCR products were analyzed in $1 \%$ agarose gel and stained with $5 \mathrm{ng} / \mathrm{ml}$ ethidium bromide and visualized under UV light.

\section{Transfections}

To study the localization of MMP-21 in cells, we transfected 293A cells with the full-length human MMP-21 construct in a pEFIRES-P expression vector (Hobbs et al, 1998) using FuGENE 6 transfection reagent (Roche, Indianapolis, Indiana), $6 \mu \mathrm{g}$ of DNA, and $9 \mu \mathrm{l}$ of FuGENE 6 per reaction. The next day the cells were given fresh complete culture medium and a day after that a medium into which $1 \mu \mathrm{g} / \mathrm{ml}$ puromycin was added to serve as a selective agent. Gradually the concentration of puromycin was increased up to 160 $\mu \mathrm{g} / \mathrm{ml}$, leaving only the fittest cell clones alive. As a negative control, we used the empty pEFIRES-P vector without any insert. The negative control was also given up to $160 \mu \mathrm{g} / \mathrm{ml}$ puromycin.

\section{Tissue Samples}

The use of paraffin-embedded, formalin-fixed samples of human fetal tissues, skin cancers, and wounds has been approved by the ethics committee of the Department of Dermatology, Helsinki University Central Hospital, Finland. Archival specimens from adult patients were obtained from the Department of Dermatopathology, Skin and Allergy Hospital, University of Helsinki, Finland and fetal tissues from Oulu University Central Hospital, Finland. Fetal age was estimated by menstrual age and macroscopic and histologic examination. All fetal material used for the immunohistochemical analysis originated from medical abortions at $7,8,10,12,14$, and 20 weeks of gestation $(n=15)$. The following adult specimens were examined: SCC of the skin [grade I $(n=5)$, grade II $(n=6)$, and grade III $(n=10)]$, basal cell cancer $(n=8)$, Bowen's disease $(n=3)$, psoriasis $(n=3)$, chronic wounds $(n=5)$, acute wounds $(n=4)$, normal skin $(n=3)$, and colon cancer $(n=4)$ (positive control). The diagnoses were confirmed by two experienced pathologists. Paraffinembedded, formalin-fixed mouse fetal samples included 10-, 13-, and 16-day-old embryos $(n=15)$ and respective placentas of NMRI mice from the Haartman Institute, University of Helsinki, Finland.

\section{Murine RNA}

Murine tissues were snap-frozen in liquid nitrogen, minced into a fine powder, and dissolved in Trizol (GibcoBRL, Life Technologies) according to the manufacturer's instructions. Total RNA was then extracted using a standard phenol precipitation technique and reverse transcribed to cDNA by using Taqman Reverse Transcription reagents (Applied Biosystems) with random hexamers as primers. Murine skin was snap-frozen in liquid nitrogen and minced into a fine powder; proteins were degraded with proteinase $\mathrm{K}$. Total RNA was then extracted using the RNeasy Miniprep Kit (Qiagen) and reverse transcribed to cDNA with Taqman Reverse Transcription reagents with random hexamers as primers.

\section{Immunohistochemistry}

Immunostaining was performed with the StreptABComplex/HRP Duet (Mouse/Rabbit) kit (Dako A/S, Glostrup, Denmark) or Vectastain Elite Rabbit kit (Vector Laboratories, Burlingame, California) (mouse tissues) using pretested dilutions of MMP-21 (1:200; Ahokas et al, 2002), MMP-7 (1:80; IM40L, Oncogene Research Products; Cambridge, Massachusetts), and $\beta$-catenin (1:1000; C19220, Transduction Laboratories, Lexington, Kentucky) antibodies. Pretreatments included trypsin (MMP-21), 95 ${ }^{\circ} \mathrm{C}$ water bath (MMP-7), or microwaving in citrate buffer ( $\beta$-catenin). Diaminobenzidine was used as the chromogenic substrate and Mayer hematoxylin as counterstain. For negative controls we used the preimmune sera, sera treated with excess immunogenic peptide as described previously (Ahokas et al, 2002), or normal rabbit/mouse lg $(\beta$-catenin/MMP-7).

\section{In Situ Hybridization}

In situ hybridization for stromelysin-2 mRNA on tissue sections was performed as described previously (Kerkelä et al, 2001). The Apoptag in situ apoptosis detection kit (Oncor Inc., Gaithersburg, Maryland) was used to detect fragmented DNA of apoptotic cells (Salmela et al, 2003).

\section{Data Mining}

We searched for putative promoters for MMP-21 by comparing upstream sequences of murine and human MMPs in the genomic sequences of AC127348 (murine) and AL360176 (human) and found only a short area, 100 nucleotides in length, that was fairly well conserved between the species (BLASTN at www.ncbi.nlm.nih.gov/ blast). After recognition of a potential promoter area, we then analyzed approximately $1.5 \mathrm{~kb}$ upstream of the first ATG codon of human and murine genomic sequences with TFSEARCH, available at http://www.cbrc.jp/ research/db/TFSEARCH.html. 


\section{Acknowledgements}

We thank Dr. Carlos Lopéz-Otín, Universidad de Oviedo, for excellent collaboration, Prof. Norbert Fusenig, DKFZ, Germany for generously providing us the HaCaT, A5, II-4, and RT3 cells, Dr. Riitta Herva for her pathology expertise, and Ms. Alli Tallqvist, Ms. Netta-Leena Nuotio, and Mr. Sami Starast for skillful technical assistance.

\section{References}

Ahokas K, Lohi J, Lohi H, Elomaa O, Karjalainen-Lindsberg M-L, Kere J, and Saarialho-Kere U (2002). Matrix metalloproteinase-21, the human orthologue for XMMP, is expressed during fetal development and in cancer. Gene 301:31-41.

Bachmeier BE and Nerlich AG (2002). Immunohistochemical pattern of cytokeratins and MMPs in human keratinocyte cell lines of different biological behaviour. Int J Oncol 20:495499.

del Barco Barrantes I, Elia AJ, Wünsch $\mathrm{K}$, de Angelis $\mathrm{MH}$, Mak TW, Rossant J, Conlon RA, Gossler A, and de la Pompa JL (1999). Interaction between Notch signalling and Lunatic fringe during somite boundary formation in the mouse. Curr Biol 9:470-480.

Bassi DE, Mahloogi H, Lopez De Cicco R, and Klein-Szanto A (2003). Increased furin activity enhances the malignant phenotype of human head and neck cancer cells. Am J Pathol 162:439-447.

Boukamp P, Petrussevska RT, Breitkreutz D, Hornung J, Markham A, and Fusenig NE (1988). Normal keratinization in a spontaneously immortalized aneuploid human keratinocyte cell line. J Cell Biol 106:761-771.

Boukamp P, Stanbridge EJ, Foo DY, Cerutti PA, and Fusenig NE (1990). c-Ha-ras oncogene expression in immortalized human keratinocytes $(\mathrm{HaCaT})$ alters growth potential in vivo but lacks correlation with malignancy. Cancer Res 50:28402847.

Chi N and Epstein JA (2002). Getting your pax straight: Pax proteins in development and disease. Trends Genet 18:4147.

Crawford HC, Fingleton BM, Rudolph-Owen LA, Goss KJ, Rubinfeld B, Polakis P, and Matrisian LM (1999). The metalloproteinase matrilysin is a target of $\beta$-catenin transactivation in intestinal tumors. Oncogene 18:2883-2891.

Fingleton B, Vargo-Gogola T, Crawford HC, and Matrisian LM (2001). Matrilysin (MMP-7) expression selects for cells with reduced sensitivity to apoptosis. Neoplasia 3:459-468.

Fusenig NE and Boukamp P (1998). Multiple stages and genetic alterations in immortalization, malignant transformation, and tumor progression of human skin keratinocytes. Mol Carcinog 23:144-158.

Game SM, Hülsen A, Patel V, Donnelly M, Yeudall WA, Stone A, Fusenig NE, and Prime SS (1992). Progressive abrogation of TGF- $\beta 1$ and EGF growth control is associated with tumor progression in ras-transformed human keratinocytes. Int $\mathrm{J}$ Cancer 52:461-470.

Gold LI, Jussila T, Fusenig NE, and Stenbäck F (2000). TGF- $\beta$ isoforms are differently expressed in increasing malignant grades of $\mathrm{HaCaT}$ keratinocytes, suggesting separate roles in skin carcinogenesis. J Pathol 190:579-588.
Gorsch SF, Memoli VA, Stukel TA, Gold LI, and Arrick BA (1992). Immunohistochemical staining for transforming growth factor- $\beta 1$ associates with disease progression in human breast cancer. Cancer Res 52:6949-6952.

Han Y-P, Tuan T-L, Hughes M, Wu H, and Garner WL (2001). Transforming growth factor- $\beta$ - and tumor necrosis factor- $\alpha$ mediated induction and proteolytic activation of MMP-9 in human skin. J Biol Chem 276:22341-22350.

Hobbs S, Jitrapakdee S, and Wallace JC (1998). Development of a bicistronic vector driven by the human polypeptide chain elongation factor $1 \alpha$ promoter for creation of stable mammalian cell lines that express very high levels of recombinant proteins. Biochem Biophys Res Commun 252:368-372.

IIIman SA, Keski-Oja J, and Lohi J (2001). Promoter characterization of the human and mouse epilysin (MMP-28) genes. Gene 275:185-194.

Impola U, Toriseva M, Suomela S, Jeskanen L, Jahkola T, Grenman R, Kähäri V-M, and Saarialho-Kere U (2003). MMP-19 is expressed by proliferating epithelium but disappears with neoplastic dedifferentiation. Int J Cancer 103: 709-716.

Kerkelä E, Ala-aho R, Jeskanen L, Lohi J, Kähäri V-M, and Saarialho-Kere U (2001). Patterns of stromelysin-2 (MMP-10) and MT1-MMP (MMP-14) expression in epithelial skin cancers. Br J Cancer 84:659-669.

Kerkelä E, Ala-aho R, Klemi P, Grénman S, Kähäri V-M, and Saarialho-Kere U (2002). Metalloelastase (MMP-12) expression by tumor cells in squamous cell carcinoma of the vulva correlates with invasiveness while that by macrophages predicts better outcome. J Pathol 198:258-269.

Kerkelä E and Saarialho-Kere U (2003). Matrix metalloproteinases in tumor progression: Focus on basal and squamous cell skin cancer. Exp Dermatol 12:109-125.

Kloen P, Gebhardt MC, Perez-Atayde A, Rosenberg AE, Springfield DS, and Gold LI (1997). Expression of transforming growth factor-beta (TGF- $\beta$ ) isoforms in osteosarcomas: TGF- $\beta 3$ is related to disease progression. Cancer 80:2230-2239.

Lange D, Persson U, Wollina U, ten Dijke P, Castelli E, Heldin $\mathrm{C}-\mathrm{H}$, and Funa K (1999). Expression of TGF- $\beta$ related Smad proteins in human epithelial skin tumors. Int $\mathrm{J}$ Oncol 14: 1049-1056.

Li AG, Koster MI, and Wang XJ (2003). Roles of TGF $\beta$ signaling in epidermal/appendage development. Cytokine Growth Factor Rev 14:99-111.

Lohi J, Wilson CL, Roby JD, and Parks WC (2001). Epilysin, a novel human matrix metalloproteinase (MMP-28) expressed in testis and keratinocytes and in response to injury. J Biol Chem 276:10134-10144.

Marchenko GN, Marchenko ND, and Strongin AY (2003). The human and mouse matrix metalloproteinase MMP-21: The structure and the regulation of the gene and the protein. Biochem J 372:503-515.

Marchenko GN, Ratvinov BI, Rozanov DV, Godzik A, Deryugina El, and Strongin AY (2001). Characterization of matrix metalloproteinase-26, a novel metalloproteinase widely expressed in cancer cells of epithelial origin. Biochem J 356 705-718.

Marin M, Karis A, Visser P, Grosveld F, and Philipsen S (1997). Transcription factor Sp1 is essential for early embryonic development but dispensable for cell growth and differentiation. Cell 89:619-628. 
McCawley LJ and Matrisian LM (2001) Matrix metalloproteinases: They're not just for matrix anymore! Curr Opin Cell Biol 13:534-540.

Nagase H and Woessner JF (1999). Matrix metalloproteinases. J Biol Chem 274:21491-21494.

Overall C and López-Otín C (2002). Strategies for MMP inhibition in cancer: Innovations for the post-trial era. Nat Rev Cancer 2:657-672.

Pardali K, Kurisaki A, Morén A, ten Dijke P, Kardassis D, and Moustakas A (2000). Role of smad proteins and transcription factor $\mathrm{Sp} 1$ in $\mathrm{p} 21^{\text {Waf1/Cip } 1}$ regulation by transforming growth factor- $\beta$. J Biol Chem 275:29244-29256.

Rechardt O, Elomaa O, Vaalamo M, Pääkkönen K, Jahkola T, Höök-Nikanne J, Hembry RM, Häkkinen L, Kere J, and Saarialho-Kere $U$ (2000). Stromelysin-2 is upregulated during normal wound repair and is induced by cytokines. J Invest Dermatol 115:778-787.

Saarialho-Kere U, Kerkelä E, Jahkola T, Keski-Oja J, and Lohi $\mathrm{J}$ (2002). Epilysin (MMP-28) is associated with cell proliferation during epithelial repair. J Invest Dermatol 119:14-21.

Saarialho-Kere UK, Crouch EC, and Parks WC (1995). Matrix metalloproteinase matrilysin is constitutively expressed in adult human exocrine epithelium. J Invest Dermatol 105: 190-196.

Salmela MT, Karjalainen-Lindsberg M-L, Jeskanen L, and Saarialho-Kere $U$ (2003). Overexpression of tissue inhibitor of metalloproteinases-3 in intestinal and cutaneous lesions of graft-versus-host-disease. Mod Pathol 16:108-114.
Suzuki AS, Tadano Y, Yamamoto T, Abe S-I, and Tajima T (2001). Expression of a novel matrix metalloproteinase gene during cynops early embryogenesis. Biochem Biophys Res Commun 288:380-384.

Truong LD, Kadmon D, McCune BK, Flanders KC, Scardino PT, and Thompson TC (1993). Association of transforming growth factor-beta 1 with prostate cancer: An immunohistochemical study. Hum Pathol 24:4-9.

Uría JA and López-Otín C (2000). Matrilysin-2, a new matrix metalloproteinase expressed in human tumors and showing the minimal domain organization required for secretion, latency and activity. Cancer Res 60:4745-4751.

Vu TH and Werb Z (2000). Matrix metalloproteinases: Effectors of development and normal physiology. Genes Dev 14:2123-2133.

Yang M, Murray M, and Kurkinen M (1997). A novel matrix metalloproteinase gene (XMMP) encoding vitronectin-like motifs is transiently expressed in Xenopus laevis early embryo development. J Biol Chem 272:13527-13533.

Zambruno G, Marchisio PC, Marconi A, Vaschieri C, Melchiori A, Giannetti A, and De Luca M (1995). Transforming growth factor-beta 1 modulates beta 1 and beta 5 integrin receptors and induces the de novo expression of the alpha $v$ beta 6 heterodimer in normal human keratinocytes: Implications for wound healing. J Cell Biol 129:853-865. 